\title{
Thiophene-3-carbonyl Chloride
}

\author{
R. Alan Aitken * (D) and Alexandra M. Z. Slawin \\ EaStCHEM School of Chemistry, University of St Andrews, North Haugh, St Andrews KY16 9ST, UK; \\ amzs@st-and.ac.uk \\ * Correspondence: raa@st-and.ac.uk; Tel.: +44-1334-463865
}

check for updates

Citation: Aitken, R.A.; Slawin,

A.M.Z. Thiophene-3-carbonyl

Chloride. Molbank 2021, 2021, M1254.

https://doi.org/10.3390/M1254

Academic Editor: Kristof Van Hecke

Received: 28 June 2021

Accepted: 20 July 2021

Published: 22 July 2021

Publisher's Note: MDPI stays neutral with regard to jurisdictional claims in published maps and institutional affiliations.

Copyright: (C) 2021 by the authors Licensee MDPI, Basel, Switzerland. This article is an open access article distributed under the terms and conditions of the Creative Commons Attribution (CC BY) license (https:// creativecommons.org/licenses/by/ $4.0 /)$.
Abstract: The X-ray structure of the title compound has been determined for the first time. It shows the ring flip disorder common among thiophene-3-carbonyl derivatives and the occurrence of this phenomenon in the structures of such compounds is discussed.

Keywords: thiophene-3-carbonyl chloride; X-ray structure; ring flip disorder

\section{Introduction}

Thiophene-3-carbonyl chloride (3-thenoyl chloride) was first described in 1938 [1] and, although it has been characterised by most analytical and spectroscopic techniques, its X-ray structure has not so far been reported, perhaps due to its relatively low melting point of $53-54{ }^{\circ} \mathrm{C}$ and the consequent difficulty in obtaining suitable crystals. In view of several recent reports of "ring flip disorder" in the structures of thiophene-3-carbonyl derivatives (Figure 1), we were interested to see whether this compound would exhibit the same phenomenon. A sample of the compound was available from our previous work [2], and it showed spectroscopic data in agreement with published values [3]. We report here its X-ray structure, which does show ring flip disorder, and survey the recent research activity in this area.
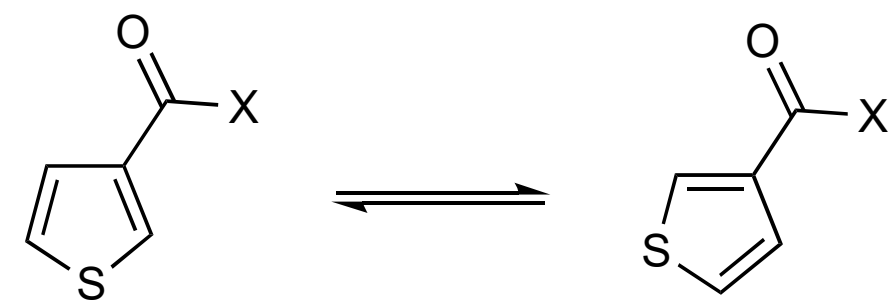

Figure 1. The nature of ring flip disorder in thiophene-3-carbonyl derivatives.

\section{Results}

Crystals suitable for diffraction were obtained by vacuum sublimation of the material obtained by reaction of thiophene-3-carboxylic acid with thionyl chloride followed by evaporation. The resulting structure (Figure 2) shows how the molecule is disordered with the acid chloride function and $\mathrm{C}(2)-\mathrm{C}(4)$ appearing as expected but the remaining two atom positions occupied optionally by either by $\mathrm{S}(1)$ and $\mathrm{C}(5) \mathrm{H}$ or $\mathrm{C}(1) \mathrm{H}$ and $\mathrm{S}(5)$. This simply corresponds to the existence of two forms differing by a $180^{\circ}$ rotation about the $\mathrm{C}(3)-\mathrm{C}=\mathrm{O}$ bond (Figure 1$) . \mathrm{S}(1)-\mathrm{C}(5)$ were refined at $70 \%$ occupancy and $\mathrm{C}(1)-\mathrm{S}(5)$ were refined at $30 \%$ occupancy. 


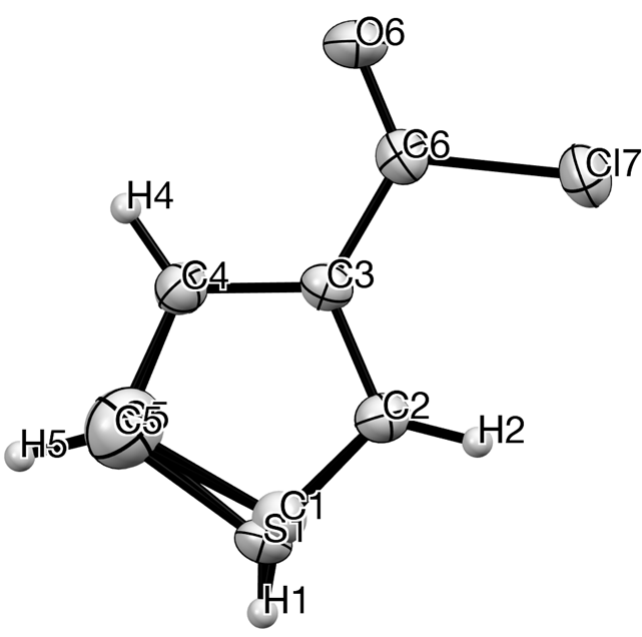

(a)

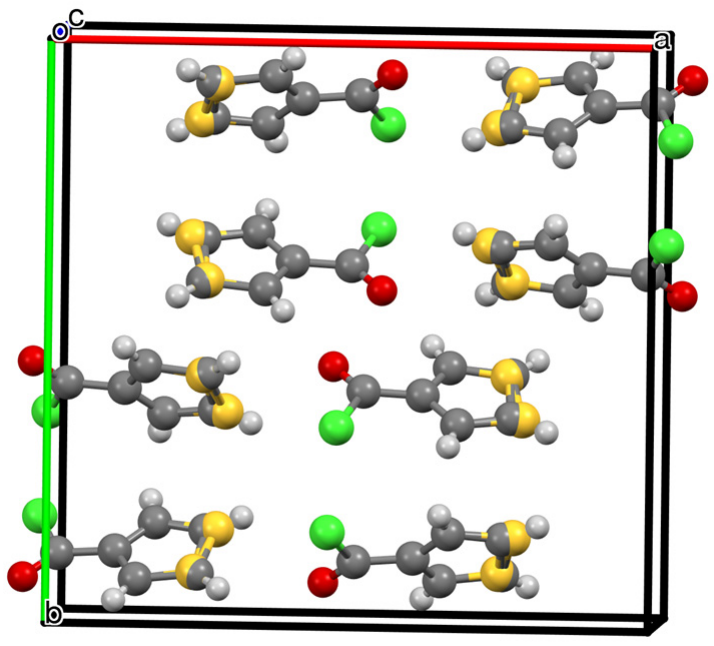

(b)

Figure 2. (a) Molecular structure of 1 with anisotropic displacement ellipsoids drawn at $50 \%$ probability level and showing numbering system used. Bond lengths and angles: $\mathrm{C}(2)-\mathrm{C}(3) 1.384(3), \mathrm{C}(3)-\mathrm{C}(4) 1.416(3), \mathrm{C}(3)-\mathrm{C}(6) 1.460(3), \mathrm{C}(6)-\mathrm{O}(6)$ 1.185(2), C(6)-Cl(7) 1.793(2) ^; C(2)-C(3)-C(4) 112.5(2), C(2)-C(3)-C(6) 126.6(2), C(4)-C(3)-C(6) 120.9(2), C(3)-C(6)-O(6) 127.1(2), $\mathrm{C}(3)-\mathrm{C}(6)-\mathrm{Cl}(7) 114.4(1), \mathrm{O}(6)-\mathrm{C}(6)-\mathrm{Cl}(7)$ 118.6(2). (b) A view of the unit cell along the $c$-axis showing the relative alignment of the 8 molecules.

As mentioned in the Introduction, there have been several recent reports of this phenomenon among thiophene-3-carbonyl derivatives. Indeed, a search of the Cambridge Structural Database (CSD) using the structure of Figure 1, where $X$ can be any group, gave 62 structures (June 2021) and of these no fewer than 22 showed the ring-flip disorder. A summary of key information for a selection of these is given in Table 1.

Table 1. X-ray structures of thiophene-3-carbonyl derivatives.

\begin{tabular}{|c|c|c|c|c|}
\hline Entry & X (Figure 2) & CSD Ref Code & Ring Flip Disorder? & Ref. \\
\hline 1 & $\mathrm{Cl}$ & - & Yes & (this work) \\
\hline 2 & $\mathrm{OH}(103 \mathrm{~K})$ & THIPAC & No & [4] \\
\hline 3 & $\mathrm{OH}(293 \mathrm{~K})$ & THIPAC01 & No & [5] \\
\hline 4 & $\mathrm{NH}_{2}$ & HUZGOB & Yes & [6] \\
\hline 5 & $\mathrm{NHCH}_{2} \mathrm{CO}_{2} \mathrm{H}$ & HUZGIV & Yes & [6] \\
\hline 6 & $\mathrm{NHCH}_{2}$-2-Pyr & TASTIR & Yes & [7] \\
\hline 7 & NHCOMe & UMIKUW & Yes & [8] \\
\hline 8 & NHCOEt & UMILAD & Yes & [8] \\
\hline 9 & $\mathrm{NHCOPr}^{\mathrm{n}}$ & UMILEH & No & [8] \\
\hline 10 & $\mathrm{NHCOBu}^{\mathrm{t}}$ & UMILIL & No & [8] \\
\hline 11 & $\mathrm{NH}-\mathrm{N}=\mathrm{CHPh}$ & ZUQZUJ & Yes & [9] \\
\hline 12 & $\mathrm{Me}$ & ISAZIM & Yes & [10] \\
\hline 13 & $\mathrm{CH}=\mathrm{C}(\mathrm{Me}) \mathrm{NH}_{2}$ & GUGMEC & Yes & [11] \\
\hline 14 & $\mathrm{CH}=\mathrm{CHC}_{6} \mathrm{H}_{4} \mathrm{Me}-4$ & WAMXOX01 & Yes & [12] \\
\hline 15 & $\mathrm{CH}_{2} \mathrm{COC}_{6} \mathrm{H}_{4}-\mathrm{NO}_{2}-4$ & SUXFEZ & Yes & [13] \\
\hline
\end{tabular}


The structure of thiophene-3-carboxylic acid (entry 2) was determined at an early date at low temperature, and this showed hydrogen bonded dimers but no disorder, with the same situation later being found at room temperature (entry 3 ) and reconfirmed by us during the current study. The structure of the amide (entry 4) was reported for the first time in late 2020 and it does show the ring flip disorder, as does the glycine derivative (entry 5), in addition to hydrogen bonding in each case. The amide derived from 2-pyridylmethylamine (entry 6) also shows such disorder. The fact that ring flip disorder may or may not occur in a series of closely related compounds is illustrated by entries 7-10 where the two imides with smaller alkyl groups do show the phenomenon but the two with larger groups do not. A further very recent example of an amide with disorder is provided by the $N$-benzylidenehydrazide (entry 11). The acetyl compound (entry 12 ) is the simplest thienyl ketone to show the effect, but several more complex carbon-based groups also do so (entries 13,14) including the recently reported 1,3-dione structure (entry 15).

The difficulty in predicting whether the ring flip disorder is likely to be observed in a given structure is emphasised by some further, more complex examples (Figure 3). In the deoxybenzoin analogue 2 (BATSEV [14]), both rings show ring flip disorder, while the structure of the benzoin analogue 3 (PUYXIQ [15]) consists of two independent molecules which each show disorder only in one ring, but the opposite one in each case. In addition, while the carboxylic acid itself does not show disorder, several metal complexes with thiophene-3-carboxylate present as a ligand do, including recent examples with manganese (VIVGIR [16], BAMSEP [17]), cobalt (JUBYUD [18]) and nickel (INEMIA [19]).

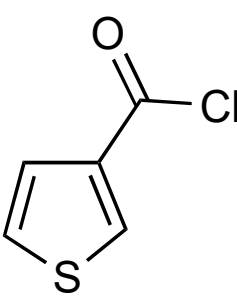

1

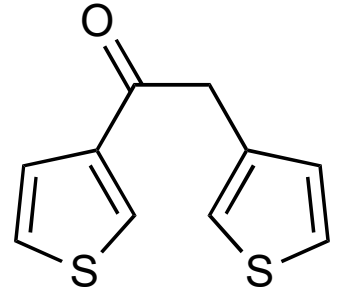

2

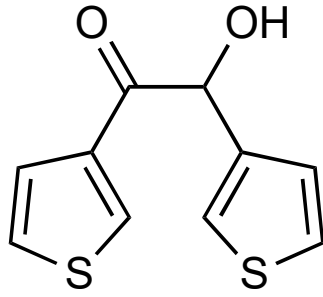

3

Figure 3. Structures showing ring flip disorder.

In summary, we obtained the X-ray crystal structure of thiophene-3-carbonyl chloride for the first time and found the molecule to exhibit ring flip disorder, as has recently been described for various other thiophene-3-carbonyl derivatives. The factors governing whether or not this phenomenon occurs in a given case are unclear.

\section{Experimental}

Suitable crystals were obtained by sublimation under reduced pressure. The structure was determined on a Rigaku SCX mini diffractometer using graphite monochromated Mo $K \alpha$ radiation $\lambda=0.71075 \AA$.

Crystal data for $\mathrm{C}_{5} \mathrm{H}_{3} \mathrm{ClOS}, M=146.59 \mathrm{~g} \mathrm{~mol}^{-1}$, colourless prism, crystal dimensions $0.28 \times 0.12 \times 0.10 \mathrm{~mm}$, orthorhombic, space group Pbca (No. 61), $a=14.8926(10)$, $b=14.4046(10), c=5.4564(3) \AA, \alpha=\beta=\gamma=90.00^{\circ}, V=1170.52(13) \AA^{3}, Z=8$, $D_{\text {calc }}=1.664 \mathrm{~g} \mathrm{~cm}^{-3}, T=173 \mathrm{~K}, R 1=0.0316, R w 2=0.0723$ for 1000 reflections with $I>2 \sigma(I)$, and 98 variables, $R_{\text {int }} 0.0618$, goodness of fit on $F^{2} 1.014$. Data have been deposited at the Cambridge Crystallographic Data Centre as CCDC 2079391. The data can be obtained free of charge from the Cambridge Crystallographic Data Centre via http:/ / www.ccdc.cam.ac.uk/getstructures (accessed on 28 June 2021). The structure was solved by direct methods and refined by full-matrix least-squares against $\mathrm{F}^{2}$ (SHELXL Version 2018/3 [20]) (Supplementary Materials). 
Supplementary Materials: The following are available online, crystallographic data in cif format.

Author Contributions: A.M.Z.S. collected the X-ray data and solved the structure; R.A.A. conceived the study, prepared the compound, analysed the data and wrote the paper. All authors have read and agreed to the published version of the manuscript.

Funding: This research received no external funding.

Data Availability Statement: The X-ray data are deposited at CCDC as stated above.

Conflicts of Interest: The authors declare no conflict of interest.

\section{References}

1. Steinkopf, W.; Schmitt, H.F. Studien in der Thiophenreihe, XLI. Einige Abkömmlinge des 3-Jodthiophens. Justus Liebigs Ann. Chem. 1938, 533, 264-269. [CrossRef]

2. Aitken, R.A.; Bibby, M.C.; Bielefeldt, F.; Double, J.A.; Laws, A.L.; Mathieu, A.-L.; Ritchie, R.B.; Wilson, D.W.J. Synthesis and antitumour activity of new derivatives of flavone-8-acetic acid (FAA). Part 3: 2-heteroaryl derivatives. Arch. Pharm. Pharm. Med. Chem. 1998, 331, 405-411. [CrossRef]

3. Martin, L.J.; Marzinzik, A.L.; Ley, S.V.; Baxendale, I.R. Safe and reliable synthesis of diazoketones and quinoxalines in a continuous flow reactor. Org. Lett. 2011, 13, 320-323. [CrossRef] [PubMed]

4. Hudson, P.; Robertson, J.H. The crystal and molecular structure of $\beta$-thiophenic acid. Acta Crystallogr. 1964, 17, 1497-1505. [CrossRef]

5. Roux, M.V.; Temprado, M.; Jiménez, P.; Dávalos, J.Z.; Foces-Foces, C.; García, M.V.; Redondo, M.I. Thermophysical, crystalline and infrared studies of the 2- and 3-thiophenecarboxylic acids. Thermochim. Acta 2003, 404, 235-244. [CrossRef]

6. Shtukenberg, A.G.; Zhu, X.; Yang, Y.; Kahr, B. Common occurrence of twisted molecular crystal morphologies from the melt. Cryst. Growth Des. 2020, 20, 6186-6197. [CrossRef]

7. Howell, S.J.; Day, C.S.; Noftle, R.E. Synthesis and characterization of 3-thiophene carboxamides containing a pyridine ring: Structure, electrochemistry, and complexation. Inorg. Chim. Acta 2005, 358, 3711-3723. [CrossRef]

8. Dai, J.; Day, C.S.; Noftle, R.E. Synthesis and structural characterization of 3-thienyl alkyl imides. Tetrahedron 2003, 59, 9389-9397. [CrossRef]

9. Rodrigues, D.A.; de Sena, M.; Pinheiro, P.; Sagrillo, F.S.; Freitas, M.C.R.; Alves, M.A.; Thota, S.; Tinoco, L.W.; Magalhães, A.; Sant'Anna, C.M.R.; et al. Structure-property relationship studies of 3-acyl-substituited furans; the serendipitous identification and characterization of a new non-classical hydrogen bond donor moiety. New J. Chem. 2020, 44, 10994-11005. [CrossRef]

10. Rozycka-Sokolowska, E.; Borowski, A.; Marciniak, B. 1-(Thiophen-3-yl)ethanone. Acta Crystallogr. Sect. C 2011, 67, o209-o211. [CrossRef] [PubMed]

11. Prek, B.; Grošelj, U.; Kasunic, M.; Zupančič, S.; Svete, J.; Stanovnik, B. Reactions of methyl ketones and (hetero)arylcarboxamides with $\mathrm{N}, \mathrm{N}$-dimethylacetamide dimethyl acetal. A simple metal-free synthesis of 2,4,6-trisubstituted pyridines. Aust. J. Chem. 2015, 68, 184-195. [CrossRef]

12. He, Y.; Su, G.; Shi, J. 3-(4-Methylphenyl)-1-(3-thienyl)-2-propen-1-one. Acta Crystallogr. Sect. C 1995, 51, 989-991. [CrossRef]

13. Davanagere, H.; Arasalike, J.; Quah, C.K.; Kwong, H.C.; Patil, P.S. Investigation of structural, physical, linear, and nonlinear optical properties of two novel thiophene centred D- $\pi$-A type push-pull organic derivatives for nonlinear optical applications. J. Mol. Struct. 2020, 1220, 128763. [CrossRef]

14. Hursthouse, M.B.; Light, M.E.; Murphy, P. Experimental crystal structure determination. CSD Commun. 2003. [CrossRef]

15. Crundwell, G.; Meskill, T.; Sayers, D.; Kantardjieff, K. 1,3-Di-3-thienyl-2-hydroxyethanone (3,3'-thenoin). Acta Crystallogr. Sect. E 2002, 58, o668-o670. [CrossRef]

16. Milios, C.J.; Inglis, R.; Vinslava, A.; Bagai, R.; Wernsdorfer, W.; Parsons, S.; Perlepes, S.P.; Christou, G.; Brechin, E.K. Toward a magnetostructural correlation for a family of $\mathrm{Mn}_{6}$ SMMs. J. Am. Chem. Soc. 2007, 129, 12505-12511. [CrossRef] [PubMed]

17. Zhou, C.-L.; Wang, Z.-M.; Wang, B.-W.; Gao, S. Two $\mathrm{Mn}_{6}$ single-molecule magnets with sulfur-contained capping ligand. Polyhedron 2011, 30, 3279-3283. [CrossRef]

18. Kim, J.; Jo, H.; Yoon, S.W.; Lee, M.H.; Choi, W.-J.; Choi, K.-Y.; Ok, K.M. Synthesis, structure, and characterization of variable chains in a series of transition metal coordination compounds. Eur. J. Inorg. Chem. 2020, 452-460. [CrossRef]

19. Su, Y.-M.; Ji, B.-Q.; Shao, F.; Zhang, S.-S.; Jagodic, M.; Jaglicic, Z.; Gao, Z.-Y.; Dou, J.-M.; Sun, D. Carboxylic acid-tuned nickel(II) clusters: Synthesis, structures, solution behaviours and magnetic properties. Dalton Trans. 2021, 50, 4355-4362. [CrossRef] [PubMed]

20. Sheldrick, G.M. A short history of SHELXL. Acta Crystallogr. Sect. A 2008, 64, 112-122. [CrossRef] [PubMed] 